\title{
CRM Competitive Strategy in Financial Institutions
}

\author{
Alireza Miremadi and Omidreza Ghanadiof
}

\section{ABSTRACT}

This research highlighted the most essential factors that have influenced CRM from the customers' side. To execute this research, the researcher has reviewed literature, design a questionnaire, and distributed 430 questionnaires among the respondents in main different cities. Furthermore, the results were analyzed through SPSS and SEM Software. This research's comprehensive CRM models try to evaluate the association of Physical Environment Quality, Products \& Services, Quality of Virtual Environment, and Quality of Electronic Banking Service as an indicator of External Customer Relationship (ECR). Moreover, this study has tried to measure the influence of Trust, Satisfaction, Commitment, and Loyalty in CRM and emphasizes the fact that CRM, ECRM, and Brand management are vital concepts systems that could enhance an organization's revenue and increase the volume of valuable customers for the banking industry.

Keywords: Strategy, Trust, Loyalty, Satisfaction, CRM, Banking.
Submitted : April 30, 2021

Published : May 24, 2021

ISSN: $2507-1076$

DOI: $10.24018 /$ ejbmr.2021.6.3.867

\section{Dr. Alireza Miremadi}

Dean \& Assistant Marketing Professor at Graduate School of Management at Sharif University of Technology - International Campus, Iran.

(e-mail: alireza.miremadi@gmail.com) Omidreza Ghanadiof

Graduated of Industrial Management, School of Technology, University of Central Missouri, USA.

(e-mail: Omidof90@gmail.com)

\section{INTRODUCTION}

Customer relationship management is a concept that emerged in the world of business since the 1980s, the concept that gains numerous attentions, by management 2018. AMR Research and Gartner valued the global market for CRM as approximately US $\$ 13$ billion [12]. CRM system can gain more profit for the company that committed to using, so the rate of satisfaction is between 52 percent and 75 percent for CRM project outcomes that consistently use over the last few years [13]. The question that overturned is why companies must learn CRM. The answer is having a lot of benefits by implementation CRM that is incredible, it means the rate of return on CRM investment is more than acceptable. Financial institutions are an excellent choice of the effectiveness of CRM since the nature of this institution is based on a close relationship with clients. Also, monitoring of CRM results system is simple as customer's account balance has been illustrated. Furthermore, this study helps to elucidate the most effective element in customer relationship management from the external aspects which is the customer's view [15]. It's intent to assesses the influence of these elements: trust, satisfaction, commitment, and loyalty. Customer loyalty is driven from the customer side, and if can be utilized properly, decently can increase competitiveness, improve customer satisfaction [25]. Thus, acquiring and retaining customers whose lifetime value to the firm is affordable, are the lifeblood of any firm [4].

\section{MATERIALS}

\section{A. Description of CRM Elements}

CRM is an abbreviation for consumer relationship management, first it is better to have a comprehensive understanding of each element of this popular concept.
Who is a right consumer?

As mentioned before customers are the main source of each organization's revenue. Therefore, the sole aim of each entity is to have, loyal and advocate customers. In this case, financial institutions whose has customer centers, have an organizational mission that is maximizing the benefit of CRM to create in deep relationship with customers to make them loyal [15]. [3]; believed in this top tier of the banking industry, organizations could engage customers affairs by doing social marketing practices. These activities not only bring a better understanding of customers but also too could bring experts for the customers and create a win-win beneficial relationship with them. Some of these enterprises that able to engage customers are placed in the next level, the ones that could excite customers; this organization used their internal models in finding valuable customers and then offered desirable relations and care about them. Also, uplevel dedicated to those entities whose could satisfy customers by engaging and exciting customers. These entities consider how to analyze customers' behavior to understand them better and pull up filtered data to make a clear pattern of their purchase [3].

\section{B. Relationship}

Creating a deep relationship with valuable customers could bring many benefits for banks, by relying on the World Bank report 2013, creating a positive experience for bank's customers could increase customers trust and confidence 50.7 percent for middle east and African banking customers and this fact put emphases on needs of CRM in the banking industry [3].

\section{Management}

[8] identified three elements for the organization:

1) There is a plan for doing works, power, and relations.

2) There are one or more power centers. 
3) There is personnel replacement.

In CRM, the term of management includes activities and process which has been done to control, plan, integrate, organize, and communicate the relationship between two parties of relation. ECRM is one of the essential key activities in industry. Most individuals as a rule drop the ' $\mathrm{e}$ ' when talking almost ECRM, they, by and large, allude to CRM, which integrated marketing, sales, and service strategies that will create more value propositions for customers [25].

\section{CRM in the Financial Services Industry}

Customer relationship management emerged as a response to increasing customer loyalty in different industries. The reasons for decreasing customer loyalty in the financial services industry are Three fundamental factors that can be identified as below [10].

\section{E. New Technological Opportunities}

The conceptual nature of financial services makes it ideal for distribution through online channels. For example, Internet makes it easier for competitors to enter a market.

\section{F. Increasing Competition}

Increasing competition by new market entrants supported by new technological opportunities and deregulation, the market for financial services is being transformed into a globally connected emporium [8].

\section{G. Brand Management and CRM}

The most radiance of branding concept was back to the mass marketing, but these companies should find a way to make relationship by the internet. Hence, in this situation companies especially, financial institutions, must use brand management along with CRM. These are some reasons that proved traditional brand management are not strong enough; Value seeking behavior, Brand proliferation Rising power of retailers, Declining TV audience, Emergence of e-commerce, Mass customization, Shift to category management, Hyper active media, Brand building without advertising 'and' Commoditization of products [23]. One of the important aspects of effective brand management is the nature of the brand image, the impression of this concept is much noticeable in a competitive market, an economic era that financial institutions play a role there. Therefore, branding is one of the most important business strategies which could make a differentiation. In the other word, it means the effective brand picture has the power to make consumer loyal and enhance overall institution's satisfaction from the customers` point of view [16].

\section{H. Proposed Model Hypothesis}

$\mathrm{H}_{1}$ : Is there any association between the Quality of the physical environment and External customer relationship management?

$\mathrm{H}_{2}$ : Is there any association between Products \& Services and External customer relationship management?

$\mathrm{H}_{3}$ : Is there any association between the Quality of the Virtual Environment and External customer relationship management?

$\mathrm{H}_{4}$ : Is there any association between the Quality of Electronic Banking Services and External customer relationship management?
$\mathrm{H}_{5}$ : Is there any association between Trust and Customer relationship management?

$\mathrm{H}_{6}$ : Is there any association between Satisfaction and Customer relationship management?

$\mathrm{H}_{7}$ : Is there any association between Commitment and Customer relationship management?

$\mathrm{H}_{8}$ : Is there any association between Loyalty and Customer relationship management?

$\mathrm{H}_{9}$ : Is there any association between ECR and Customer relationship management.

\section{CRM Objectives}

CRM objectives helps marketers and organization to understand the CRM concept and some common and general CRM benefits which in turn gains more acceptance for CRM practices and needs of CRM studies too.

\section{J. Tree Waves in CRM}

As you can see in this Table I, we can conclude there are three classified CRM: Operational CRM, Analytical CRM, and Collaborative CRM.

\begin{tabular}{|c|c|}
\hline Waves in CRM & Description \\
\hline Operational CRM & $\begin{array}{l}\text { Help organizations in order to enhance their business } \\
\text { process. CRM software applications enable the } \\
\text { marketing, selling and service functions to be } \\
\text { automated and integrated; some of these implications } \\
\text { could be mentioned as: marketing automation, } \\
\text { market segmentation, campaign management, event } \\
\text { - based (trigger) marketing, sales force automation, } \\
\text { account management, service automation, case } \\
\text { (incident or issue) management, inbound } \\
\text { communications management, service level } \\
\text { management }\end{array}$ \\
\hline Analytical CRM & $\begin{array}{l}\text { Refer to the process of acquiring, accumulating, } \\
\text { squeezing, mixing, processing, interpreting, } \\
\text { distributing, using, and reporting customer - related } \\
\text { data to enhance both customer and company value. } \\
\text { This is a main point that operational CRM could not } \\
\text { be work effectively in the absence of analytical } \\
\text { information about consumers. }\end{array}$ \\
\hline $\begin{array}{l}\text { Collaborative } \\
\text { CRM }\end{array}$ & $\begin{array}{l}\text { Describe position in which we have well strategically } \\
\text { arrangement between distinct enterprises in the } \\
\text { supply chain in order to capture and maintaining } \\
\text { more profitable consumers }\end{array}$ \\
\hline
\end{tabular}

\section{K. The QCI Model}

The goal of the QCI Model is consumer satisfaction and retaining. For having customer retention, one must work in a different aspect by considering the external and internal sides. The external environment such as customers, suppliers, people, and organizations. Internal like staff and management that by the help of them could organization manage consumers, raise consumers experience, have a better analyzing and planning, enhancing value generation mechanism. the loop of consumer management activity provided by this model includes these stages: targeting, conversion, identifying, delivering, retention activity, value development, managing dissatisfied clients, and make them return through this study, i.e., tries to achieve better insight from consumer means knowing them better. 


\section{Brand Management and Its Different Dimensions}

A brand is a set of associations that are linked to a product, division, or company. These associations settle in the memory of customers. Brands represent an enormously valuable piece of legal property, that capable to influence consumer behavior, sales, and provide a secure source of revenues. Brand image is the consumer's perception that is reflected by the brand association in the consumer's memory. Definition of brand image is to process of conveying emotional value which is come from the quality of products or services. what is remains in the mind of customers, is a response about a brand that is revealed in their behavior. Therefore, a strong emotional relationship and positioning of the bank's brand could bring reliable power for market positioning. This strategy is beneficial for those financial institutions that want to be a winner in the war among competitive to gain more revenue [16]. The other important aspect in the management of brand image is the role of internal customers because of the good influence that brand image can bring on quality perception value. This factor must be a vital factor in service evaluation. Perhaps these facts emphasize that people buy a bundle of products or services which has a brand [7]. There is one delicate point, that an institution is responsible for the brand. It means each person of each financial institution is the bank's ambassador. Positive brand image makes higher expectation and eventually make them, loyalty to the system. Therefore, it requires paying attention more to their needs. Finally, personnel's innovation is the best promoting tool for enhancing a brand's position and make a pioneer institution in the market [16]. Everyone knows that how word of mouth can be powerful. This important success is gained if customers see themselves in a strong relationship with their partners and they wish to have a mutual benefit in this connection, CRM is a reliable way that promises to do this in a very effective way.

As methodology type, research applied the mixed-method approach that consisted of qualitative and quantitative questionnaires for this research. The questionnaire was applied as a measurement tool that contains several types of questions especially five-point Likert scales for measuring the conceptual proposed model. The respondents were asked to reflect the extent of influence of variables on the measured variable from very high to very low. To run Pilot testing, 70 questionnaires were distributed among respondents randomly and gained their opinion to measure thesis objectives. Cronbach's Alpha was measured internal consistency among the constructs that are settled in a good place [13]. Face and content validity are methods of validity that could be used, for measuring content validity used from three main sources: academic expert opinion, reviewing the literature, a professional expert like a bank manager. This study is based on simple random sampling.

The researcher distributed 470 questionnaires among the respondents in the target cities, and then received 430 questionnaires that indicated the acceptance rate of 91.5 percent. The research ran SPSS.v 25 and Lisrel as statistical tools to perform the analysis.

\section{RESEARCH METHODOLOGY}

As methodology type, research applied the mixed-method approach that consisted of qualitative and quantitative questionnaires for this research. The questionnaire was applied as a measurement tool that contains several types of questions especially five-point Likert scales for measuring the conceptual proposed model. The respondents were asked to reflect the extent of influence of variables on the measured variable from very high to very low. To run Pilot testing, 70 questionnaires were distributed among respondents randomly and gained their opinion to measure thesis objectives. Cronbach's Alpha was measured internal consistency among the constructs that are settled in a good place [13]. Face and content validity are methods of validity that could be used, for measuring content validity used from three main sources: academic expert opinion, reviewing the literature, a professional expert like a bank manager. This study is based on simple random sampling.

The researcher distributed 470 questionnaires among the respondents in the target cities, and then received 430 questionnaires that indicated the acceptance rate of 91.5 percent. The research ran SPSS.v 25 and Lisrel as statistical tools to perform the analysis.

\section{DATA ANALYSIS}

Respondent profile: Table II presents the characteristic which is addressed to a personal profile. As result declared $58.4 \%$ of respondents preferred state bank services whereas $26.5 \%$ used that indicated private banks are more popular among people. When they want to use internet service banking in Iran. It is also interesting to know $46.7 \%$ are male and $53.3 \%$ female. The majority of respondents' ages are between 21-40 which captured $84.2 \%$ that shows the respondents are young and comfortable using internet service banking since they are educated enough to fill up the questionnaire.

\section{A. Confirmatory Factor Analysis of Proposed Models}

ECR first-order confirmatory factor analysis. In the first part of the measurement of the ECR model (including indicator variables and latent variables of first-order), the conceptual model is investigated and measured. After the formation of the first-order measurement model of ECR, the $\mathrm{T}-\mathrm{value}$ indicator will be evaluated to prove the significant coefficient path. Fig. 1 showed the $t-$ value variables of the ECR first-order measurement model. T-value test statistic is based on the significant coefficients path, in other words, the coefficient is significant at 0.05 levels if the absolute T-value is greater than 1.96. Fig. 1 showed that all variable's T-value is greater than 1.96, and it showed that they are indicative and meaningful which means that these variables are significant in the ECR model. The meaningful of variables has been proved that coefficient of variables is also meaningful in this model at 0.05 levels. ECR Second-order confirmatory factor analysis. 
TABLE II: RESPONDENT'S PROFILES

\begin{tabular}{|c|c|c|c|}
\hline & & Frequency & Percent \\
\hline \multirow{7}{*}{ Type of Bank } & Private Bank & 114 & 26.5 \\
\hline & Public Bank & 251 & 58.4 \\
\hline & Public - Private Bank & 50 & 11.6 \\
\hline & Credit Union & 6 & 1.4 \\
\hline & Financial Institution & 5 & 1.2 \\
\hline & Missing & 4 & 0.9 \\
\hline & Total & 430 & 100.0 \\
\hline \multirow[t]{4}{*}{ Gender } & Man & 201 & 46.7 \\
\hline & Woman & 225 & 52.3 \\
\hline & Missing & 4 & 0.9 \\
\hline & Total & 430 & 100.0 \\
\hline \multirow[t]{7}{*}{ Age } & Less than 20 Years Old & 25 & 5.8 \\
\hline & $21-30$ Years Old & 261 & 60.7 \\
\hline & $31-40$ Years Old & 101 & 23.5 \\
\hline & $41-50$ Years Old & 26 & 6.0 \\
\hline & More than 50 Years Old & 15 & 3.5 \\
\hline & Missing & 2 & 0.5 \\
\hline & Total & 430 & 100.0 \\
\hline \multirow[t]{8}{*}{ Education } & Less than Diploma & 1 & 0.2 \\
\hline & Diploma & 35 & 8.1 \\
\hline & Associate Degree (2years) & 16 & 3.7 \\
\hline & Graduation Degree & 171 & 39.8 \\
\hline & Master Degree & 175 & 40.7 \\
\hline & PHD and More & 30 & 7.0 \\
\hline & Missing & 2 & 99.5 \\
\hline & Total & 430 & 100.0 \\
\hline \multirow[t]{9}{*}{ Occupation } & Student & 186 & 43.3 \\
\hline & Employee & 126 & 29.3 \\
\hline & Specialist & 50 & 11.6 \\
\hline & Business & 44 & 10.2 \\
\hline & Retired & 9 & 2.1 \\
\hline & Housekeeper & 6 & 1.4 \\
\hline & Unemployed & 7 & 1.6 \\
\hline & Missing & 2 & 0.5 \\
\hline & Total & 430 & 100.0 \\
\hline Job & None & 120 & 27.9 \\
\hline \multirow[t]{6}{*}{ Experience } & Less than 1 Years & 50 & 11.6 \\
\hline & $1-3$ Years & 81 & 18.8 \\
\hline & Between $3-5$ Years & 39 & 9.1 \\
\hline & More than 5 Years & 132 & 30.7 \\
\hline & Missing & 8 & 1.9 \\
\hline & Total & 430 & 100.0 \\
\hline \multirow[t]{6}{*}{ Income Level } & Less than 1 Million Tomans & 180 & 41.9 \\
\hline & $1-3$ Million Tomans & 132 & 30.7 \\
\hline & 3-5 Million Tomans & 25 & 5.8 \\
\hline & More than 5 Million Tomans & 8 & 1.9 \\
\hline & Missing & 85 & 19.8 \\
\hline & Total & 430 & 100.0 \\
\hline
\end{tabular}

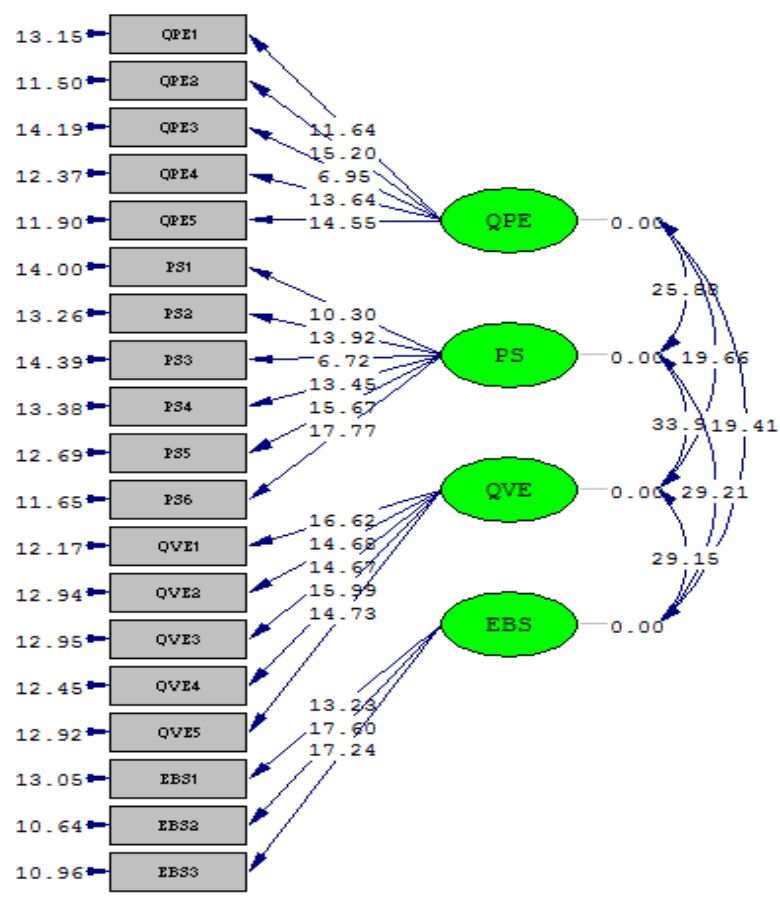

Fig. 1. T - value variables of ECR first-order measurement model.
After reviewing the ECR first-order measurement model through statistical inferential, it is time to review the second ECR latent variables. As we observed all the indicator variable's absolute T-value is greater than 1.96 . Therefore, all indicators should be placed in the proper range to indicate how to fit for the ECR model and it is known as the goodness of fit indicators.

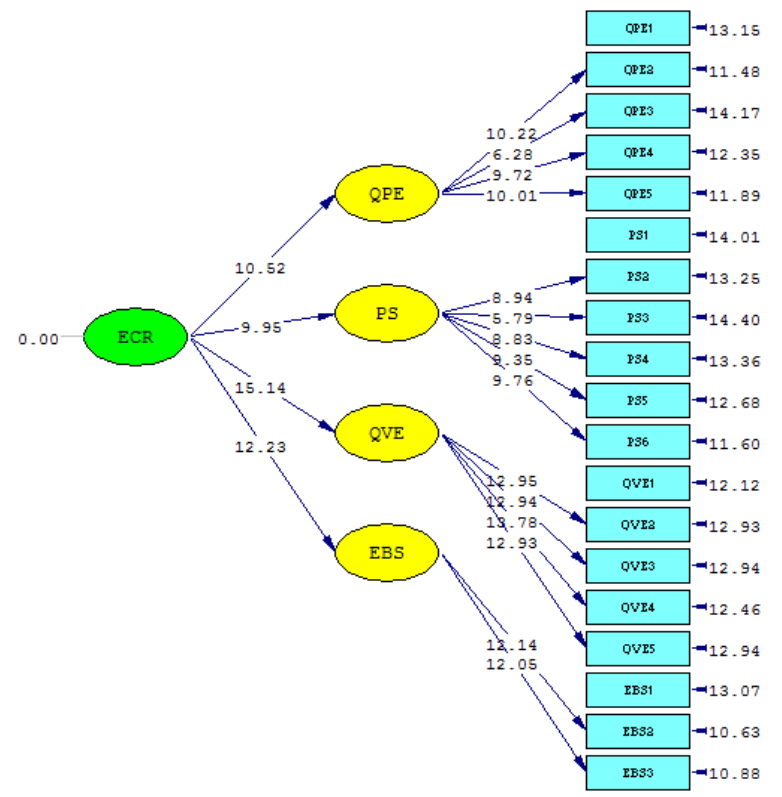

Fig. 2. T - value variables of ECR second - order measurement model.

With the above result, the ECR second-order measurement model is confirmed, and the researcher has measured the CRM first-order measurement model with trust, satisfaction, commitment, and loyalty as latent variable of CRM model. CRM first order confirmatory factor analysis.

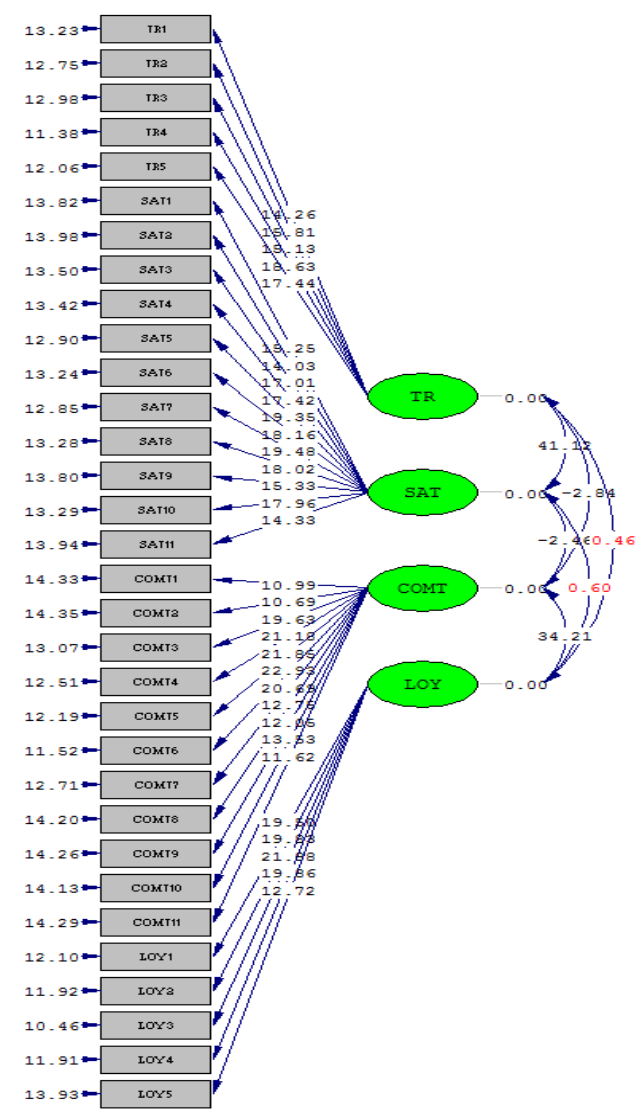

Fig. 3. T - Values for first - order measurement model for CRM. 
As you can see from the above figure, all the T-value is greater than 1.96, therefore coefficient path is meaningful at 0.05 level. CRM second-order confirmatory factor analysis. After confirming the first-order measurement of latent variables with its indicator variables, the model should be assessed by the second-order measurement model. As you can observe from Fig. 4 all the t-value between latent variables (trust, satisfaction, commitment, and loyalty) are greater than 1.96. Besides, the $\mathrm{T}-$-value of all the latent variables with CRM is greater than 1.96 except for the Tvalue between Loyalty and CRM that was not meaningful at 0.05 level.

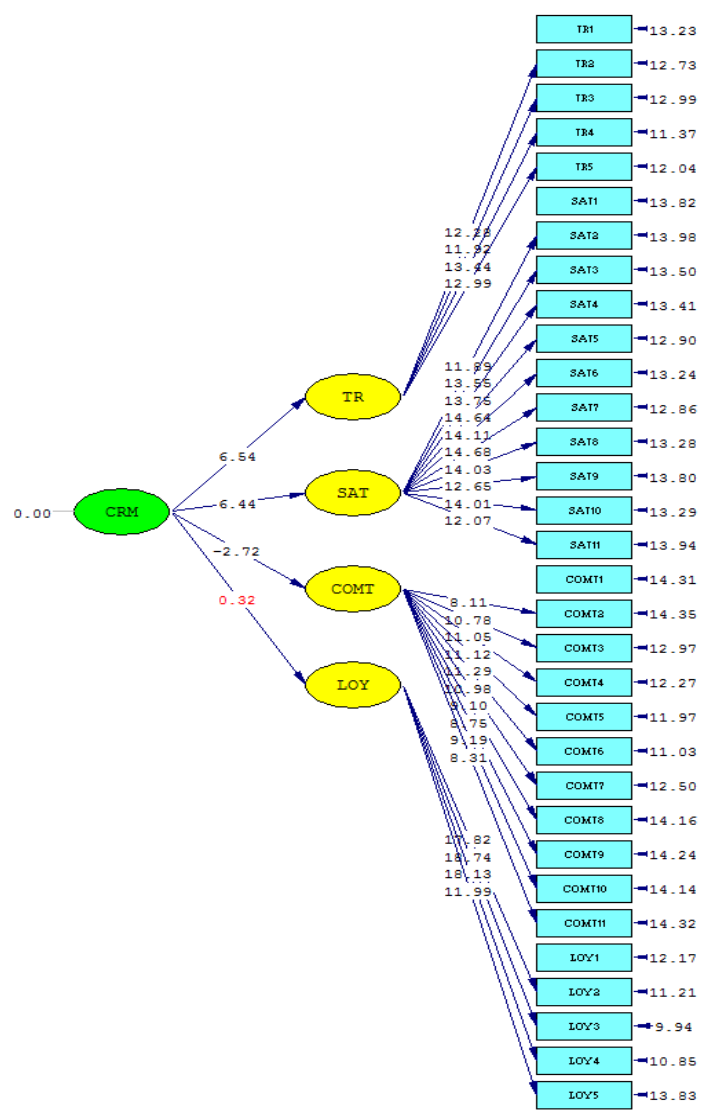

Fig. 4. T-Values for the second-order measurement model for CRM.

\section{B. Final Review of Research Conceptual Model}

After the conformity model of ECR and CRM individually, the result indicated that each model is confirmed separately, the researcher's interest is to measure the research conceptual model.

As the figure indicated, all the T-values between the latent variables and indicators are greater than 1.96 and meaningful at 0.05 level. Furthermore, the result declared that all the $t-$ values for latent variables are greater than 1.96 except among the loyalty and CRM. Effectiveness of indicator for the research model. For this purpose, the indicators should be placed in the proper range to indicate the goodness of fit for the perceptual model, and it is known as the goodness of fit index.

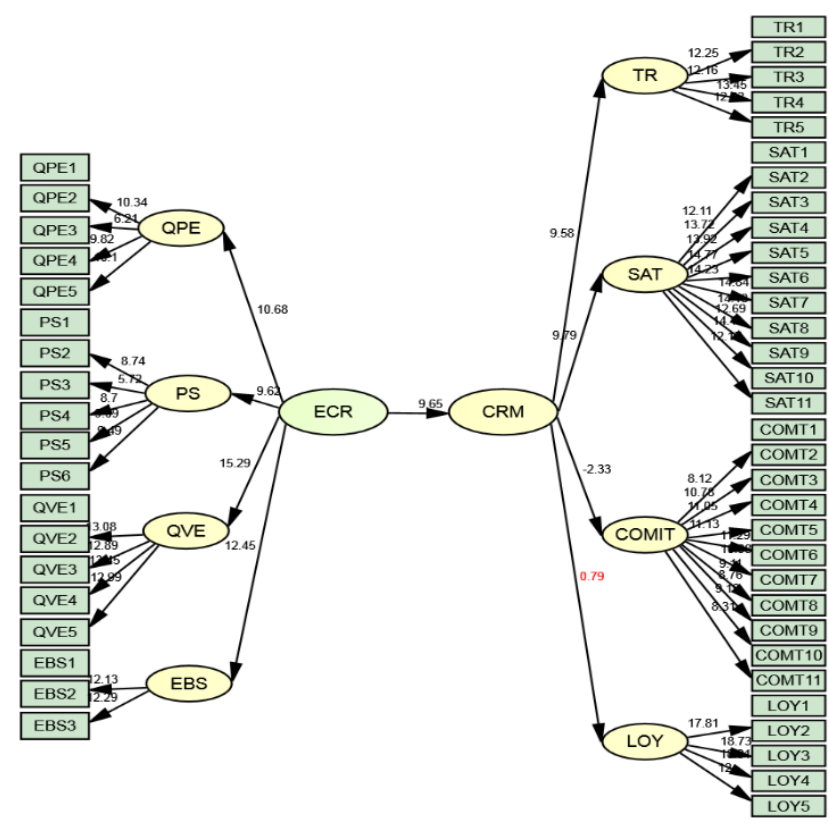

Fig. 5. T-Values for the conceptual model.

As Table III showed all the indexes are placed in the acceptable range. The optimal value is lower than the desirable level [16]. However, other parameters of the conceptual model are in the optimal range [21]. Therefore, the research conceptual model is highly confirmed [5], and we can conclude the research hypothesis from the conceptual model.

\section{The Research Hypothesis of the Factor Analysis Result}

The conclusion of the research hypotheses is presented in Table IV. The above table showed the standard coefficient Tvalue for each path of result which is addressed to the research hypothesis. As the table indicated all the hypotheses are accepted except for the $\mathrm{H} 8$ because of $\mathrm{T}$-value is less than the 1.96 in 0.05 confidence level. All the remaining hypotheses are supported because all the absolute $\mathrm{T}$-values are greater than 1.96. When you look at the standard coefficient the CRM-COMT is considered as the reverse relationship between them.

\begin{tabular}{cccccc}
\multicolumn{7}{c}{ TABLE IV: RESEARCH HYPOTHESIS RESULT } \\
\hline Parameter & Estimate & $\begin{array}{c}\text { STD- } \\
\text { error }\end{array}$ & $\begin{array}{c}\text { T- } \\
\text { value }\end{array}$ & Hypothesis & Result \\
\hline ECR $\rightarrow$ QPE & 0.83 & 0.08 & 10.68 & H1 & Supported \\
ECR $\rightarrow$ PS & 0.94 & 0.10 & 9.62 & H2 & Supported \\
ECR $\rightarrow$ QVE & 0.92 & 0.06 & 15.29 & H3 & Supported \\
ECR $\rightarrow$ EBS & 0.92 & 0.07 & 12.45 & H4 & Supported \\
CRM $\rightarrow$ TR & 0.94 & 0.07 & 9.58 & H5 & Supported \\
CRM $\rightarrow$ SAT & 0.90 & 0.06 & 9.79 & H6 & Supported \\
CRM $\rightarrow$ COMT & -0.13 & 0.05 & -2.33 & H7 & Supported \\
CRM $\rightarrow$ LOY & 0.04 & 0.05 & 0.79 & H8 & Not \\
ECR $\rightarrow$ CRM & 0.89 & 0.09 & 9.65 & H9 & Supported \\
\end{tabular}

\begin{tabular}{ccccccc}
\multicolumn{7}{c}{ TABLE III: GoodNESS OF FIT INDICES FOR THE RESEARCH MoDEL } \\
\hline$\chi^{Y} / d f$ & $\begin{array}{c}\text { Standardized RMR } \\
\text { (SRMSR) }\end{array}$ & $\begin{array}{c}\text { Root Mean Square Error } \\
\text { of ApproXimation } \\
\text { (RMSEA) }\end{array}$ & $\begin{array}{c}\text { Normed Fit } \\
\text { IndeX (NFI) }\end{array}$ & $\begin{array}{c}\text { Non-Normed Fit } \\
\text { IndeX (NNFI) }\end{array}$ & $\begin{array}{c}\text { Comparative } \\
\text { Fit IndeX } \\
(\text { CFI) }\end{array}$ \\
\hline 2.724 & 0.118 & 0.063 & 0.938 & 0.959 & 0.961 \\
\hline
\end{tabular}

Optimal values: $\frac{x^{2}}{d f} \leq 3 ; N F I, N N F I, C F I \geq 0.9 ; R M S E A \leq 0.08 ; S R M S R \leq 0.1$. 


\section{CONCLUSION}

In summary, we could say that federal and private banks are the most famous and reputed among the financial institution that captured 58.4 and $26.5 \%$ of respondents. The study discovered that $43.3 \%$ of respondents were from educated segmentation since this study tries to capture educated opinion about the ECRM in financial institutions. It is also interesting to know $46.7 \%$ are male and $53.3 \%$ female. Most respondents ages are between 21-0 that captured $84 \%$ that shows the respondents are young and comfortable using online service banking. Furthermore, most respondents have more than five years of experience that could be segmented in the range of medium economic tier.

The three priorities of respondents about the quality of the physical environment are an appropriate distribution of bank branches, design of the internal environment, and geographical location of branches. Therefore, the financial institutions need to select the best location for branches that caused maximum access for customers.

For product and service factors: Reluctant to Purchasing Product, Attractive Financial Service, and Bank Service Credit indexes have a maximum value. Hence it could be concluded that financial institutions should concentrate more on providing user-friendly services for their consumers, especially in e-banking. This is a fact that current financial services and products are not so attractive, and all the institutions provide almost similar services.

The researcher also discovered that: Available Online Bank Replication Service, Clear Condition Bank Electronic Service, online customer service are the most valuable services. it proved that financial institutions should concentrate more on online services. Electronic Banking is categorized into a group with a variety of indexes ranking such as user-friendly online services, the content of website, accuracy, and validity of online services has the most effect on the quality of the relationship between the financial institution and their consumers in the online banking services area. ECR model tries to evaluate the association of four main constructs of Quality of Physical Environment, Products and Services, Quality of Virtual Environment, and Quality of Online Banking Service on the dependent variable of ECR (External consumer relationship). The result could be ranked as QVE (Quality of Virtual Environment), EBS (Electronic Banking Services), QPE (Quality of Physical Environment), PS (Product and Service) this means qualities of the virtual environment and online banking services have the greatest impact on the improvement of the relationship between financial institutions and their consumer. The three most values for the trust index are categorized as follows: Trust Bank Responsibility, Responsibility for Mistake, Equal Facility. This order of priorities showed that financial institutions must work better in their support services, acceptance of mistakes, and allocation of budget to have a better CRM performance. Consumer satisfaction always is a good indicator for measuring the organization's performance. Therefore, each entity needs to know about the main factor that influences satisfaction. Satisfaction can be achieved by considering Courtesy, Responsiveness, Competence, Access, and Understanding consumer's needs. As the result proved the following indexes such as Respect for the customer, responsiveness, knowledgeable staff to give a response to the consumer, optimal distribution of branch, and understanding the consumer needs, are captured in the mind of consumers and impact more on CRM enhancement and especially consumer satisfaction. Trust and satisfaction have major influences on CRM. Hence in financial institutions, these factors should be considered as major competitive advantages. From these facts, we can conclude that a very strong relationship has been between ECR and CRM. it indicated a highly precise variable for measuring the attractiveness of online banking systems and their influence on CRM that was studied in this research.

TABLE V: RANK OF PROPOSED MODEL, Most POPULAR INDEXES

\begin{tabular}{|c|c|c|c|}
\hline $\begin{array}{c}\text { Rank of most } \\
\text { popular } \\
\text { variables }\end{array}$ & $\begin{array}{c}\text { T-value } \\
\text { of } \\
\text { constructs }\end{array}$ & Rank of most popular indexes & $\begin{array}{c}\mathrm{T} \text {-value of } \\
\text { indexes }\end{array}$ \\
\hline $\begin{array}{l}\text { Quality of } \\
\text { virtual } \\
\text { environment }\end{array}$ & 15.14 & $\begin{array}{l}\text { QVE1 (Available online bank } \\
\text { replication service) } \\
\text { QVE4(Clear condition bank } \\
\text { electronic service) } \\
\text { QVE5 (Reply message to } \\
\text { website) }\end{array}$ & $\begin{array}{l}16.62 \\
15.99 \\
14.73\end{array}$ \\
\hline $\begin{array}{l}\text { Quality of } \\
\text { electronic } \\
\text { banking } \\
\text { service }\end{array}$ & 12.23 & $\begin{array}{c}\text { EBS2(Precise online activity) } \\
\text { EBS3(User friendly } \\
\text { electronic services) } \\
\text { EBS1(Website content) }\end{array}$ & $\begin{array}{l}17.60 \\
17.24 \\
17.23\end{array}$ \\
\hline $\begin{array}{c}\text { Quality of } \\
\text { physical } \\
\text { environment }\end{array}$ & 10.52 & $\begin{array}{c}\text { QPE2(Bank branch } \\
\text { distribution) } \\
\text { QPE5(Internal environment) } \\
\text { QPE4(Branch location) }\end{array}$ & $\begin{array}{l}15.20 \\
14.55 \\
13.64\end{array}$ \\
\hline $\begin{array}{c}\text { Products and } \\
\text { services }\end{array}$ & 9.95 & $\begin{array}{c}\text { PS6(Reluctant to purchasing } \\
\text { product) } \\
\text { PS5(Attractive financial } \\
\text { service) } \\
\text { PS2(Bank Service Credit) }\end{array}$ & $\begin{array}{l}17.77 \\
15.67 \\
13.92\end{array}$ \\
\hline Trust & 6.54 & $\begin{array}{c}\text { TR4(Trust Bank } \\
\text { Responsibility) } \\
\text { TR5(Responsibility for } \\
\text { mistake) } \\
\text { TR2(Equal facility) }\end{array}$ & $\begin{array}{l}18.63 \\
17.44 \\
15.81\end{array}$ \\
\hline Satisfaction & 6.44 & $\begin{array}{l}\text { SAT7(Courtesy) } \\
\text { SAT5(Responsiveness) } \\
\text { SAT6(Competence) } \\
\text { SAT8(Access) } \\
\text { SAT10(Understand } \\
\text { consumer) }\end{array}$ & $\begin{array}{l}19.48 \\
19.35 \\
19.25 \\
18.16 \\
18.02\end{array}$ \\
\hline
\end{tabular}

Managerial implementation: Brands add emotion and trust to the products and services, providing clues that simplify consumer's choices and help to initiate and maintain a strong relationship. Hence based on the results of researchers and our experience, the main factors (Trust, Satisfaction, and Loyalty) have a positive impact on the brand.

According to the table VI, the comparison of consumer's trust among different type of banks reveals that public, public-private, and private banks have 21.4, 20.33, and 19.97 means values in one sample T-test examination respectively with a cut point of 15 which means there is a good confidential relationship between public banks and private banks.

For satisfaction and loyalty, these statistics results emphasize that there is no more satisfaction in consumers of public banks than private ones with a minuscule difference of approximately two-point in one sample T-test examination. There is a sensible difference between public and publicprivate banks with seven differences in means of them in the mentioned test. Finally, for the loyalty factor the sign value of the test was not in the acceptable domain for public and private-public banks but for private banks was the 16.61 value 
with a cut point of 15 that is barely acceptable, these items could have a positive effect on consumers brand preference. A brand is a promise to achieve a certain result, deliver a certain experience, or act in a certain way. A promise that is conveyed to people to see, hear touch, taste, or smell about the business. Therefore, a good institution's record and credit in past along with a long-term offering of products and services have better awareness, recognition, and emotion from customers.

TABLE VI: COMPARE TRUST, SATISFACTION, LOYALTY AMONG DIFFERENT TYPE OF BANKS

\begin{tabular}{ccccccc}
\multicolumn{7}{c}{ DIFFERENT TYPE OF BANKS } \\
\hline Variable & Bank type & N & Mean & t & f & $\begin{array}{c}\text { Sig (2- } \\
\text { tailed) }\end{array}$ \\
\hline Trust & Private bank & 34 & 19.9706 & 7.351 & 33 & 0.000 \\
Trust & Public bank & 25 & 21.6400 & 7.864 & 24 & 0.000 \\
Trust & $\begin{array}{c}\text { Public }- \\
\text { private bank }\end{array}$ & 9 & 20.3333 & 7.542 & 8 & 0.000 \\
Satisfaction & Private bank & 34 & 45.0588 & 9.082 & 33 & 0.000 \\
Satisfaction & Public bank & 25 & 47.0800 & 7.526 & 24 & 0.000 \\
Satisfaction & $\begin{array}{c}\text { Public }- \\
\text { private bank }\end{array}$ & 9 & 40.4444 & 2.239 & 8 & 0.056 \\
loyalty & Private bank & 34 & 16.6176 & 2.081 & 33 & 0.045 \\
loyalty & Public bank & 25 & 13.2000 & -1.659 & 24 & 0.110 \\
loyalty & $\begin{array}{c}\text { Public }- \\
\text { private bank }\end{array}$ & 9 & 14.4444 & -0.607 & 8 & 0.560 \\
\hline
\end{tabular}

One of the pros of brand image which makes it so important in the field of banking is the matter of risk. Each product and service have a diverse bundle of risk which impacts on customer's decision processes such as functional risk, physical risk, social risk, financial risk, psychological risk, and time risk. For the banking services, a positive image could decrease the tension of remarkable and effective risks of financial, psychological, and time risk since brand management practices offers in this case too.

\section{REFERENCES}

[1] Bloemer J, de Ruyter K, Peeters P. Investigating drivers of bank loyalty: the complex relationship between image, service quality and satisfaction. Int J Bank Mark. 1998;16(7):276-86.

[2] Wruuck P, Speyer B, Ag DB, Hoffmann R. Pricing in retail banking. Scope for boosting customer satisfaction. Frankfurt am Main: Deutsche Bank AG; 2013.

[3] Davies G, Chun R. Gaps between the internal and external perceptions of the corporate brand. Corporate reputation review. 2002 Oct;5(2):144-58.

[4] DUBINSKY, A. J. 1999. When salespeople fail: assessing blame. Industrial Marketing Management, 28.

[5] Mohsenin S, Esfidani M. Structural equation modeling using LISREL software. Ketabe Mehraban Publication, 2014.

[6] ETZIONI, A. 1975. A comparative analysis of complex organizations. Free Press.

[7] Fardhosseini, M. S., Soltaninejad, M., Karji, A., Ghorbani, Z., \& Ghanadiof, O. (2021). Qualitative Evaluation of 5S Application Considering the Experience of Electrical Construction Experts.

[8] Ghanadiof, O. (2017). Customer loyalty and powerful brand in heavy machinery industry (Doctoral dissertation, University of Tehran).

[9] Körner, V. A. Z. 2000. Management of customer relationship in business media-The case of the financial industry. IEEE Computer Society Press.

[10] Krishnan, M. S. R., V.; Meyer, M.C.; and Damien, P. 1999. Customer satisfaction for financial services: The role of products, services, and information technology. Management Science.

[11] Leenheer, J., \& Bijmolt, T. H. A. 2007. Which retailers adopt a loyalty program? An empirical study. Journal of Retailing and Consumer Services.

[12] Marion Steel A, C. D., Michael T. Ewing 2013. Developing customised CRM projects: The role of industry norms, organisational context and customer expectations on CRM implementation Industrial Marketing Management.

[13] Miremadi.Ar,Cheraghi.H,Khaligh.AR (2012), "Gaining Competitive Advantage Through Marketing Strategies In Container Terminal :A Case Study Of Shahaid Rajaee Port In Iran", International Business Research , Canadian center of Science and education ,Vol 5,No.2, February 2012, Toronto,Canada.

[14] Miremad Ar, Khoei K (2013), “ The Art of Visual Merchandising on Consumer Buying Behavior", International Journal Contemporary Business Studies 4 (6), 34-50 Nargesian, A. 2013. Using LISREL Software for Structural aeaquation Modeling.

[15] Ghanadiof, O., Miremadi, A., \& Kenar roudi, J. (n.d.). 'Evaluation on Role of Electronic Word of Mouth (EWOM) Ads in Customers' Emotions and Choices in E-Shops'. (2021).

[16] Onyancha, G. K. 2013. The Impact of Bank Brand Image on Customer Satisfaction and Loyalty: A Case of Kenya Commercial Bank. European Journal of Business and Management, 5.

[17] Parsons, T. 1960a. Structure and process in modern societies Glencoe. Free Press.

[18] Pokharel, B. Customer Relationship Management: Related Theories, Challenges and Application in Banking Sector. Banking Journal, 1.

[19] Seyed Mohammad Seyed Hosseini, A. M., Mohammad Reza Gholamian 2010. Cluster analysis using data mining approach to develop CRM methodology to assess the customer loyalty. Elsevier.

[20] Shirin Ranjabr Toutouee, A. M. 2014. Developing Strategic Approach to Electronic Bankingservice and CRM in Iranian Banking Industry. Indian Journal of Science Research.

[21] Sorbom, K. G. J. A. D. 1993. Structural Equation Modeling with the Simplis Command Language.

[22] Walter 2000. Customer relationship management in banks - from pure transaction orientation to a comprehensive relationship approach. Banking and Information Technology.

[23] Xavier MJ. Fall of traditional brand management: Making way for CRM and business equity. Chennai: Academy for management Excellence. 2004. 